\title{
June $195^{6}$
}

Vol. LXX No. 6

\section{The Joumal of}

\section{Laryngology and ()tology}

\author{
EDITED BY
}

\author{
WALTER HOWARTH \\ ASSTSTANT EDTTOR \\ G. H. BATEMAN \\ WITH THE COLIABORATION OF \\ Sir V. NEGUS R. G, MACBETH
}

\section{Contents}

Paralysis of the: PHaryax

Paralysis of the Pharynx

Paralysis of the Phakyxx

Extra IABYRINTHINE VARTIGO DUE to Cervical Musci.e Lusions

WEBER'S TEET AND RECRUITMENT.

Chtnical RecoRns-

Goux as a Causie of Tespikatory Orstruetion .

A CASE of Chondroma of tHB NASTPHARYAX: .
F. A. ELriotr

J. B. HARMAN 2

CHARLES КЕОGH

I. P. GraY

G. A. MOULDEN

J. B. CAVENAGH

J. E. BLUNDKLL-

WILLAMMS

A. B, N. RAO -

GeNeral Notrs

London

Headley Brothers Ltd

rog Kingsway $\mathrm{W} \mathrm{C}_{2}$ 


\title{
The Journal of \\ Laryngology and Otology
}

(Founded in 1887 by Moruale MhGKenzre and Norkis WOLFENDENy)

\author{
EDITED BY \\ WALTER HOWARTH
}

\author{
ASSISTANT EDTTOR \\ G. H. BATEMAN
}

WITH THE COLIADORATIOA OF

Sir V. NEGUS R. G. MACBETH

x. Original Articles are accepted on the condition that they have not been published elsewhere.

2. Manuscripts should be typewritten, on one side only of the paper, and well spaced. Captions to illustrations should be typed on a separate sheet and sent at the same time as original photographs etc.

The Harvard system of recording references should be used, e.g. Grens, C., and Brown, D. (r95x) J. Laryng., 65, 33. Abbreviations of Journals should follow the style recommended in World Medical Periodicals, published by World Health Organization $x 952$.

It is most important that authors should verify personally the accuracy of every reference before submitting a paper for publication.

3. Galley proofs and engraver's proots of illustrations are sent to the author. Corrections, which should be kept to a minimum must be clearly marked, and no extma matter added. Proofs should be returned within s days.

4. IIlustration blocks are provided free up to the limit of fs per article; beyond this authors are expected to pay half the cost. Coloured illustrations will be charged in full to authors.

Blocks will normally be held by the Printers for three years after which they will be destroyed. Any author who has borne a part of the cost of his blocks is entitled to have these returned to him, but a request for this must be sent within three years of the appeanance of the article, to Hradiex Broxirss LrD, rog Kingsway London, W $\mathrm{C}_{2}$.

5. Orders for reprints should be sent when retuming galley proofs, and for this purpose specinl forms are supplicd.

6. Authors of original communications on Oto-Laryngology in other journals are invited to send a copy, or two reprints, to the Journal of Laryngology. If they are willing, at the same time, to submit their own abstract (in English, French, Italian, or German) it will be welcomed.

7. Editorial communications may be addressed to THR Eprror, fournal of Larymgology, c/0 HesDi.sX Brotruers LTD., 109 Kingsway London, WC2.

8. The annual subscription is three guineas sterling (U.S.A. \$ Io) post free, and is payable in advance,

9. Single copies will be on sale at $75,6 \mathrm{~d}$. each; copies of parts up to Vol. LXiil may be purchased at 45 . each.

xo. All subscriptions, advertising and business communications should be sent to the publishers, Headiex Brotmens. LTD., 109 Krngswax London, $\mathrm{WC}_{2}$.

\section{United Staks of America}

Orders for this Journal may be sent through local bookseller, or to Stecumer-Harnerk, INC., $3 x-33$ East 10 th Street, New York, or direct to the

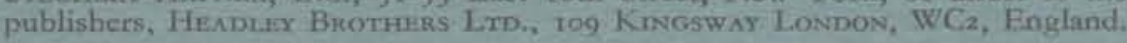

Please mention The Journal of L Laryngology when replying to advertisements 


\title{
PLAIN TALK about hearing aids
}

\author{
N U M B E R S E V E N
}

\section{What is a Home Trial?}

As far as we're concerned a home trial begins the very minute you leave your Multitone Centre with a hearing aid. From our wide range of transistor instruments we've picked the one which seems to suit you best: now you take it away for seven days and really try it out. Try it at home, in the street-in as many different places, under as many different conditions, as possible.

When seven days are up come back and see us again.

Perhaps you'll tell us you wouldn't have the aid at any price, and if so we'll part without hard feelings and without you being a penny the poorer. But the chances are you'll say 'Yes, it suits me, but-'. And that's the whole point and purpose of the trial: your 'but' will help us to make the final adjustments which turn a good aid into one exactly suited to your hearing. That's a real home

trial for you, carried out in the letter and the spirit of the National

Institute for the Deaf Agreement, to which we are signatozies. If your doctor thinks a hearing aid might help you, and you want such a trial, call in at your nearest Multitone Centre. Write to us at Dover Street and we'll send you the address.

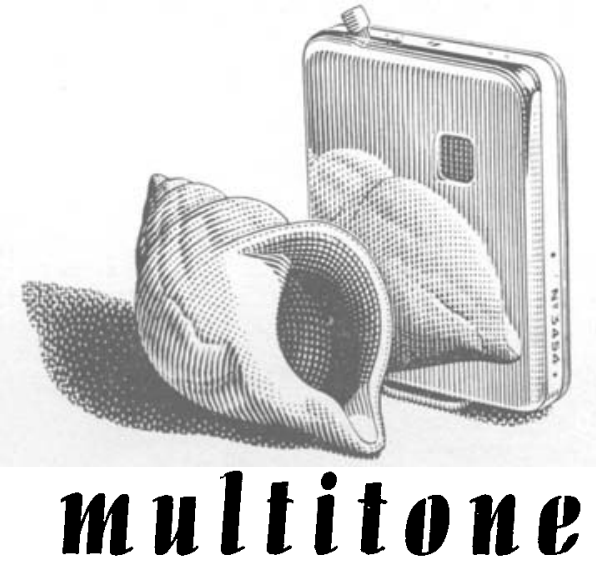

H E A R I N G A I D S

MULTITONE ELECTRIC COMPANY LIMITED

25, Dover Street, London, W.I. Telephone: HYDe Park 9977

Signatories to the National Institute for the Deaf Agreement.

Branches at: LONDON, BRIGHTON, BIRMINGHAM, CARDIFF, DUBLIN, EDINBURGH, GLASGOW, TORQUAY.

AGENTS THROUGHOUT GREAT BRITAIN AND OVERSEAS. 


\section{ADVERTISEMENTS}

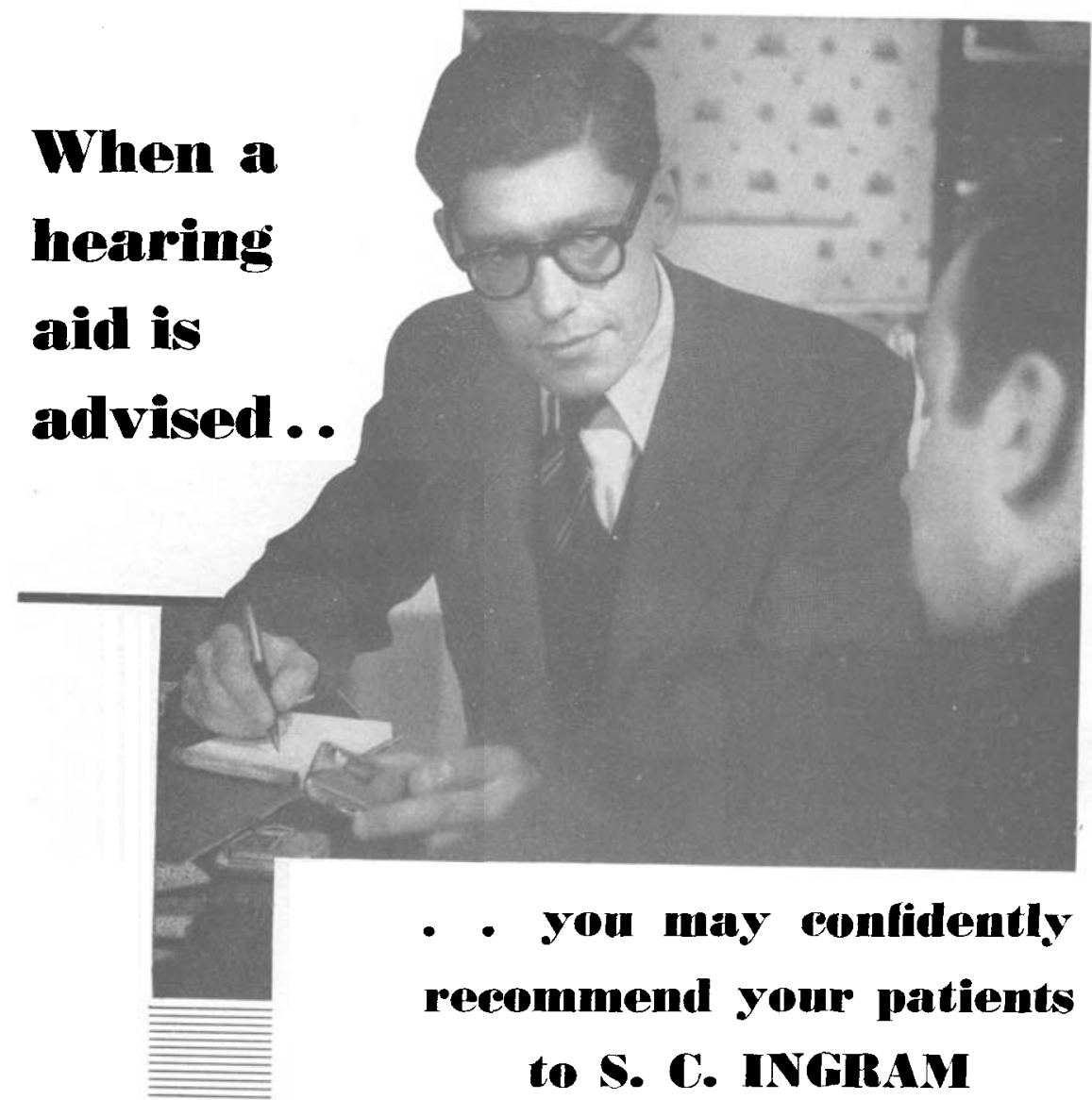

* They can try the different makes of hearing aids

* They get impartial advice on all makes of hearing aids

* Their personal needs are given individual and continued attention

$\star$ A full report on each fitting recommended is sent to the patient's ear specialist

* They can compare at one consultation the different makes one with another

\section{S. C. DNGMAMM Independent Hearing Aid Consultant}

On the approved List of the National Institute for the Deaf

2 SHEPHERD STREET, SHEPHERD MARKET, LONDON, W.I

Hyde Park 9042

Please mention The Journal of Laryngol $g$ when replying to advertisements 


\title{
The finest
}

\section{Hearing Aid}

in the

World

\author{
is made in
}

England by Amplivox

\ VERY WIDE RANGE OF

FREQUENCY RESPONSE

The advanced circuit design of the

Amplivox "A" series ensures an excep-

tionally wide frequency response with

a correspondingly high standard of

clarity of sound reproduction

unequalled in any other hearing

aid manufactured either in

Europe or in America

$\star$ VERY WIDE RANGE OF

ADJUSTMENTS FOR

INDIVIDUAL FITTING

The Amplivox " $A$ " series models are outstanding for their range of

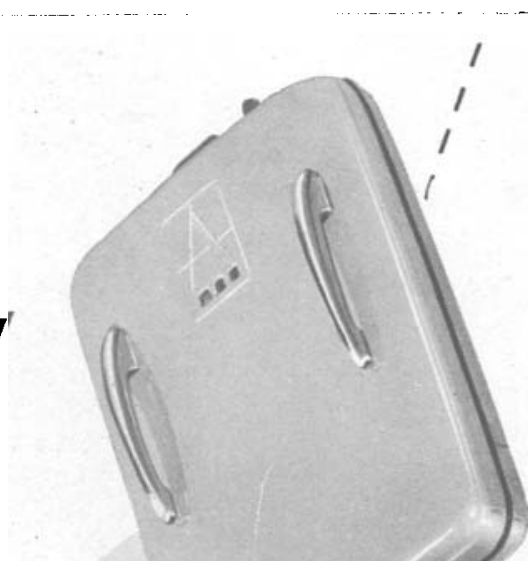

adjustments, designed to meet all types of hearing loss. The fitting facilities of the instruments include selective amplification of high and low notes and automatic volume compression. A 3-volt battery can be used in place of the standard $1 \cdot 5$ volt battery to provide extra gain and amplification for the very deaf. In design and performance Amplivox Hearing Aids lead the world

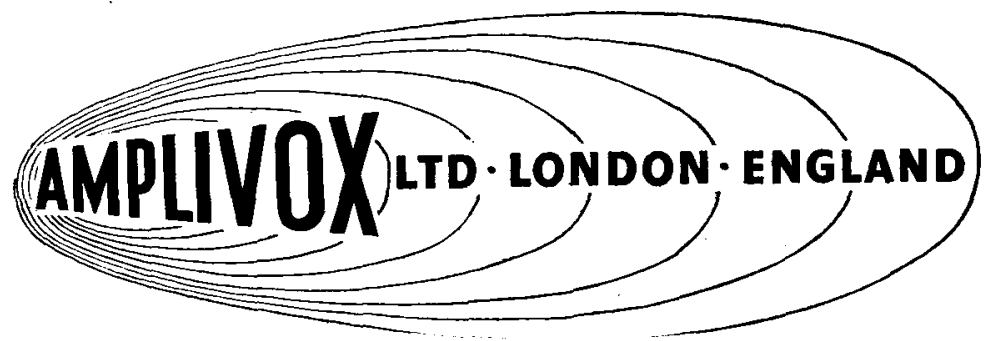

47/48 New Bond Street, London, w.

Hyde Park $9888-9$ W O R L D - W I D E

D I S T R I B U T I O N

A $\mathbf{N} \mathbf{D}$

S E R V I C E

Please mention The Journal of Laryngology when replying to advertiscments 


\section{EAR WAX \\ Removed this easy way}

The removal of wax from the external auditory meatus has, in the past, normally entailed attendance by the

patient for diagnosis and for the prescription of a suitable loosening agent, and a second attendance a few days later for syringing.

Now, by the use of Cerumol Ear Drops, wax can be removed in most cases at one visit. A few drops of Cerumol can be instilled into the ear and, while another patient is being attended to, the soft cerumen dissolves and the harder wax disimpacts. The wax can then be removed by gentle syringing or with cotton wool. The wax may even be found to run out of the ear on its own accord, in which case patients themselves may instil

Cerumol at home, obviating further attendances. Cerumol is anti-bacterial, non-irritating and harmless to the lining of the external auditory meatus or the tympanic membrane.

Cerumol is included in Category No. 4 of the M.O.H. classified list and may be prescribed on N.H.S. Form E.C.1n

\section{CERUMOL}

Distributors in U.K.

TAMPAX LIMITED, BELVUE ROAD, NORTHOLT, GREENFORD, MIDDLESEX. Telephone: WAXlow 2244 If you wish to test for yourself and have not received recently a 10. c.c. vial please write or telephone direct to:

LABORATORIES FOR APPLIED BIOLOGY LTD.,

91, AMHURST PARK, LONDON, N.16 Tel, : STA 2252
EAR DROPS

for the easier removal of

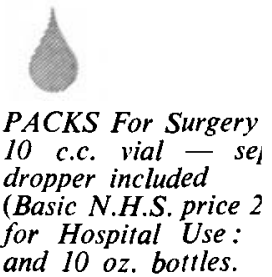

Please mention The Journal of Laryngolog' when replying to advertisements 


\section{AMPLIVOX MODEL $6 I$ \\ THE CLINICAL AUDIOMETER OF INTERNATIONAL REPUTE}

"Messrs. Amplivox were among the first firms to produce an audiometer in this
country, and their larger model is one of the best instruments of the kind now made country, and their larger model is one of the best instruments of
in the world at a competitive price." - The LANCET, 23-12-50.

- Eleven exact test Irequencies 125-12,000 c.p.s.

- Simplified hearing loss dial. The same set of figures is read for both bone and air conduction at all frequencies, and for speech.

- Bone conduction tests can be made from 125-4,000 c.p.s.

- Masking Tone calibrated in decibels, permitting accurate control of masking.

- Double Air receivers enable test tones to be switched instantly from ear to ear.

- Speech test circuit monitors speech level, permitting accurate measurement of hearing loss for speech.

- Loudness Balance Control establishes presence of recruitment in monaural deafness.

- Automatic voltage compen. sator.

Recruitment Test Set accessory establishes presence of recruitment by amplitude modulation, enabling each ear to be tested independently.

Speech Turntable, English made P.B. and Harvard Spondee Records available.

Full details are available from the manufacturers who will gladly arrange demonstrations if required.

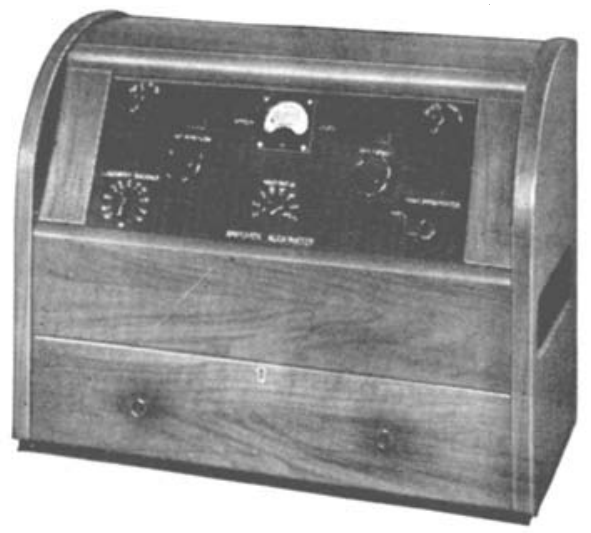

\section{The Basic Instrument of Modern Otology}

ACCURATE • COMPLETE • SIMPLE TO OPERATE

AMPLIVOX LTD., 2 BENTINCK ST., LONDON, W.I (Welbeck 259I) 


\title{
BROMPTON HOSPITAL PATTERN OPERATING TABLE
}

\author{
IMPROVED MODEL
}

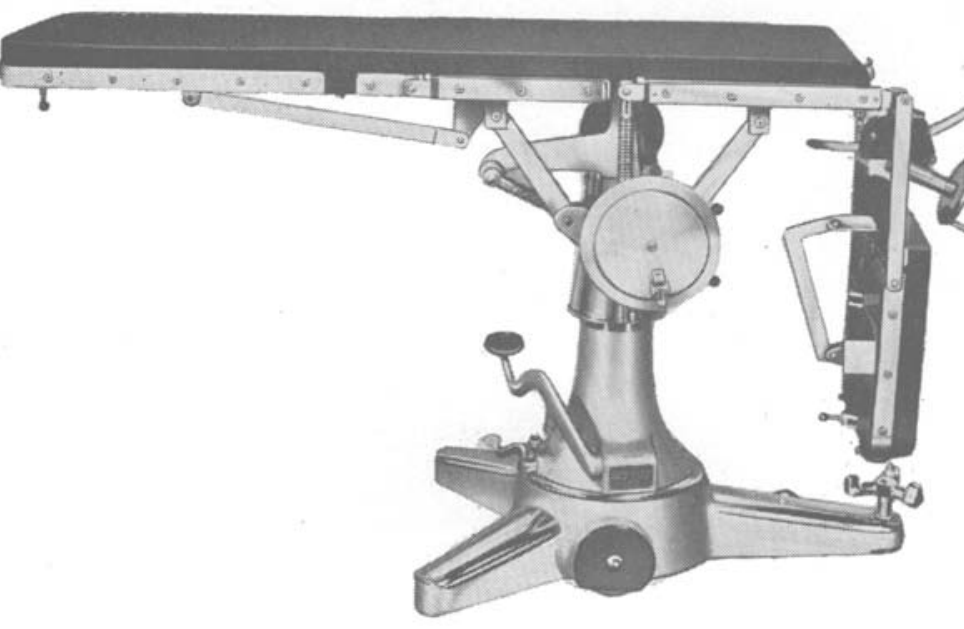

$M A D E B Y$

\section{$\mathbf{T}_{\mathrm{HE}} \mathbf{G}_{\text {sxiro }} \mathbf{U}_{\text {suaur }} \mathbf{M}_{\mathrm{FG} .} \mathbf{C}_{\mathrm{o}} \mathbf{L}_{\mathrm{TD}}$}

28a, 33 \& 34 DEVONSHIRE STREET, LONDON, W. SURGICAL AND OPTICAL INJ TRUMENT MAKERS

Telephone :

WELBECK 2835 (3 lines)
Telegrams :

CYSTOSCOPE, WESDO, LONDON

Please mention The Journal of Laryngology when replying to advertisements 


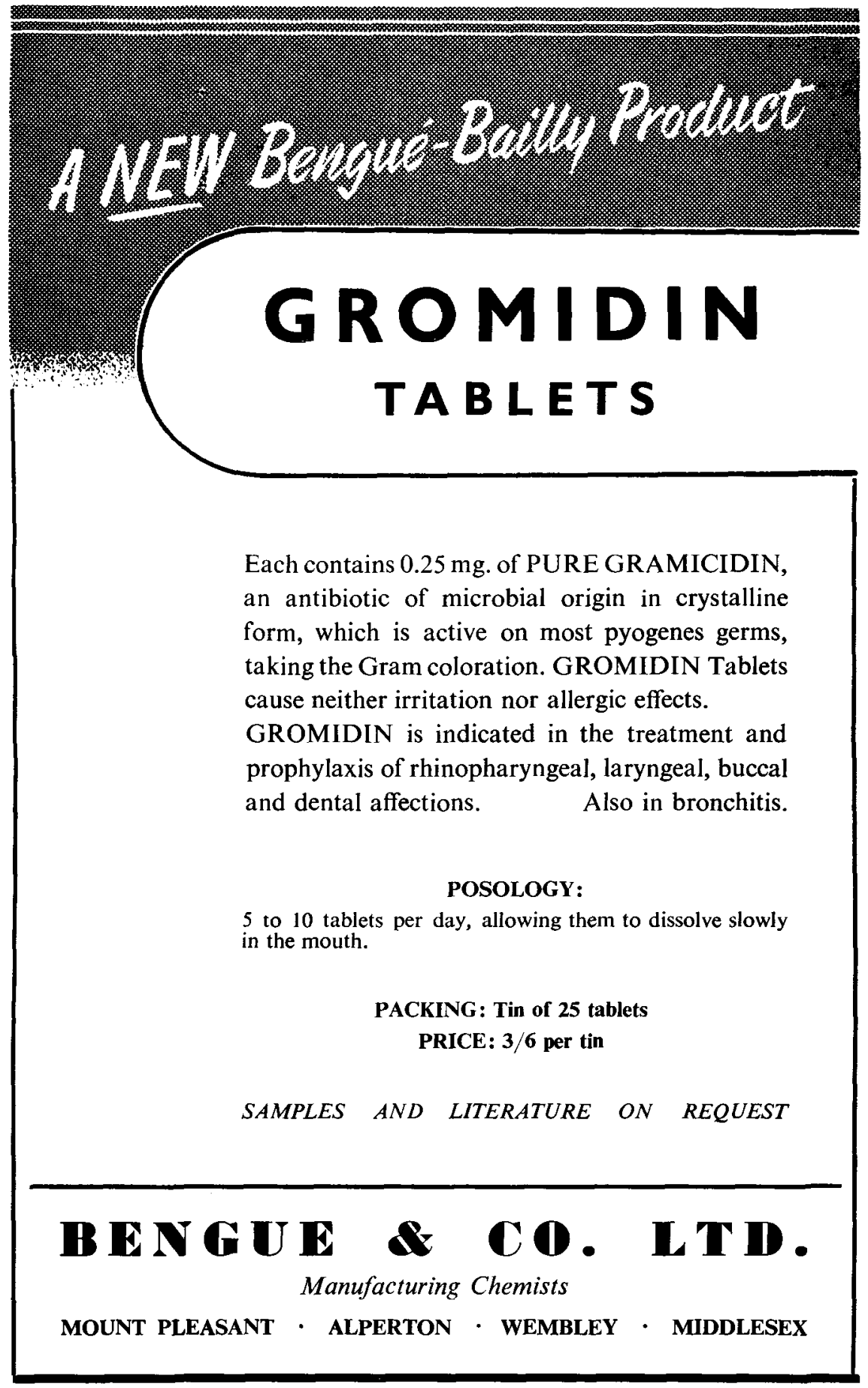

Please mention The Journal of Laryngology when replying to advertisements 


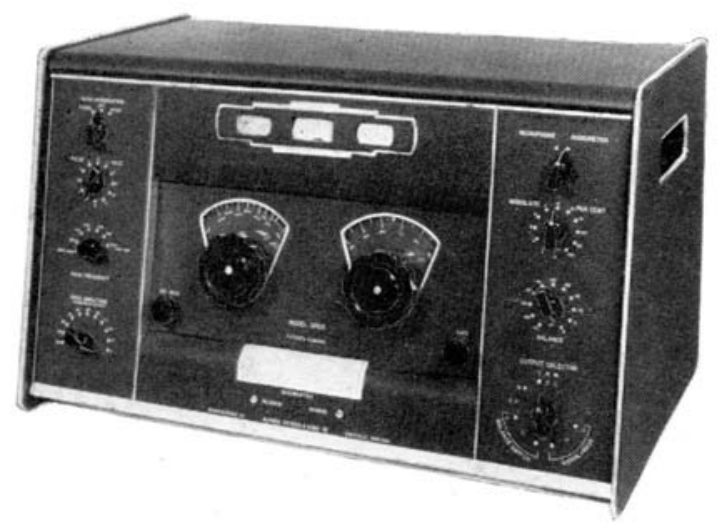

\section{INVALUABLE AIDS}

\section{TO DIAGNOSIS}

THE RANGE of the internationally known Peters audiometers is designed to meet all audiometric requirements, from those of a large Clinic to audiometric tests in schools.

In addition to a large speech audiometer for free-field work the range includes three pure-tone audiometers:

The SPD $/ 2$ Clinic Audiometer illustrated above, a most comprehensive instrument providing many facilities for advanced techniques. The SPD/ 3 Consulting Audiometer designed to meet all normal audiometric needs.

The SPD/1 Portable (Basic Diagnostic) the most recent addition to the range, which ideally fills basic requirements in a portable form.

All three instruments offer a single zero reference level for all measurements, the Peters patented continuously variable attenuator and provision for simple speed audiometry. All are made to the same high standard, differing only in the facilities which they offer.

For the convenience of specialists all these instruments are available for demonstration at the Acousticon Showrooms or, on request, at the specialist's consulting room or hospital.

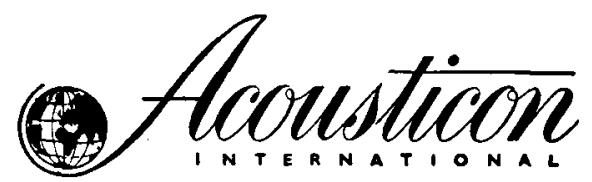

Literature and any information on request:

122 Wigmore Street, London, W.1. Telephone: Welbeck 0935

St. Ann's Arcade, 12 Si. Ann's Square, Manchester.

Telephone: Blackfriars 2109

128 Hope Sireet, Glasgow, C.2. Telephone Central 4634

ALFRED PETERS AND SONS LIMITED, VICTORIA WORKS, GELL STREET, SHEFFIELD, 3

Please mention The Journal of Laryngolog: when replying to advertisements 


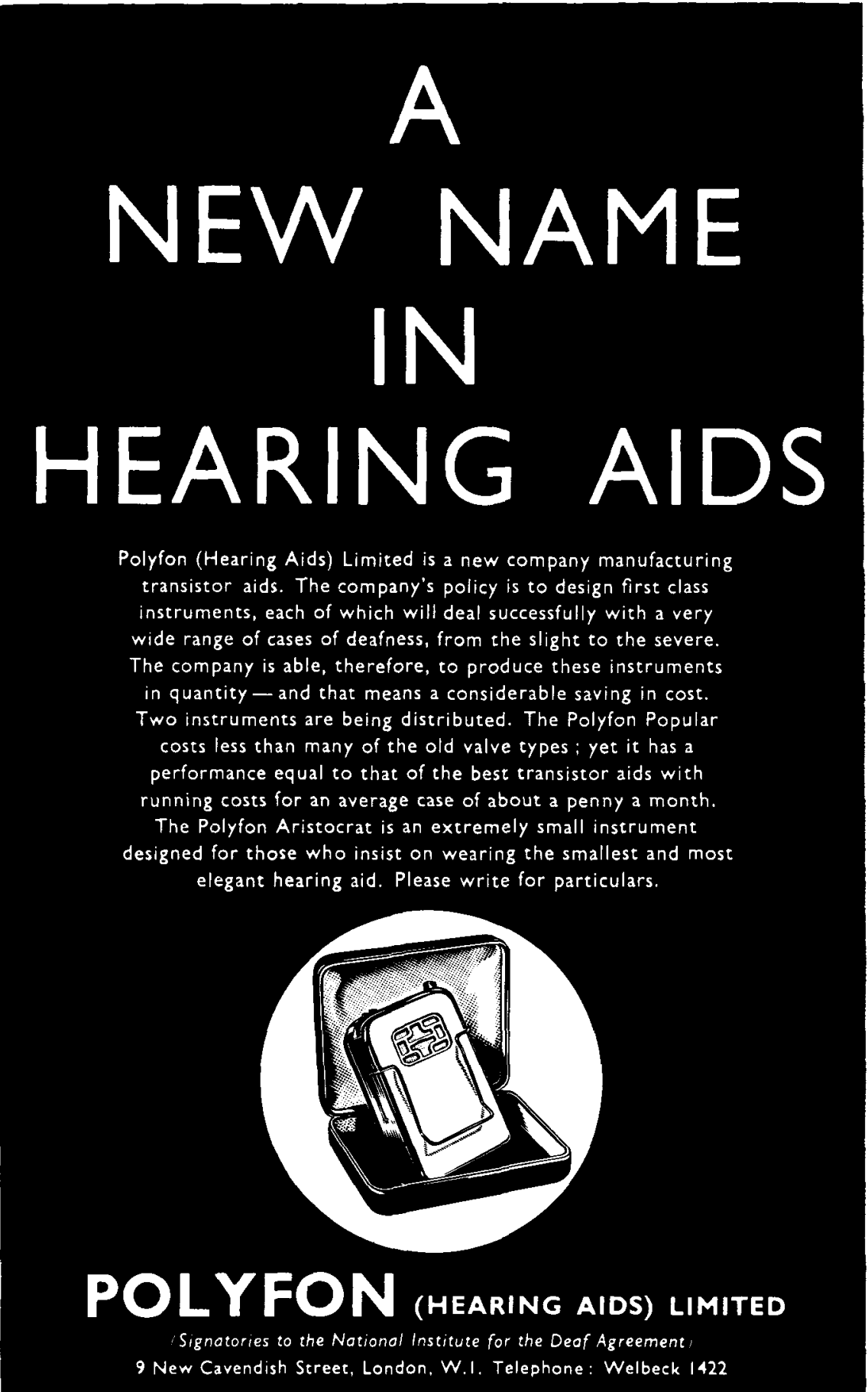

Please mention The Journal of Laryngology when replying to advertisements 


\section{CONTENTS}

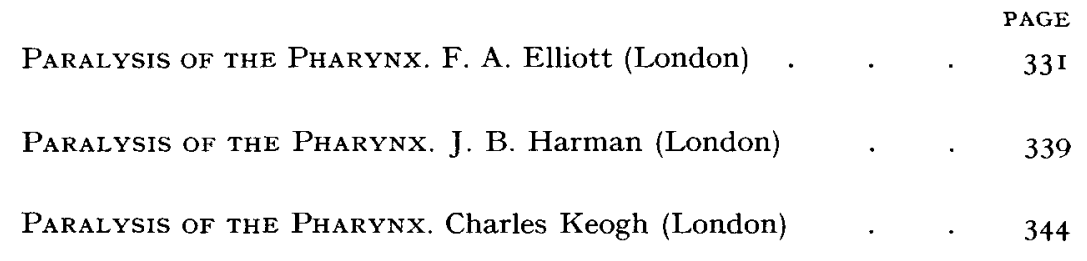

Extra Labyrinthine Vertigo due to Cervical Muscle Lesions. L. P. Gray (Perth, W.A.) • • . . . . $35^{2}$

Weber's Test and Recruitment. G. A. Moulden (Liverpool) 362 Clinical Records-

Gout as a Cause of Respiratory Obstruction. J. B. Cavenagh (Worcester) and J. E. Blundell-Williams (Tenbury Wells) 365

A Case of Chondroma of the Nasopharynx. A. B. N. Rao (Hyderabad)

For Advertisement space in this Journal apply to: HEADLEY BROTHERS Ltd, 109 Kingsway London W C 2

Please mention The Journal of Laryngology when replying to advertisements 